\title{
Appraisal of Different Tomato Genotypes against Scirtothrips dorsalis (Thysanoptera: Thripidae) Infestation with Reference to Morphologi- cal Plant Characters
}

\author{
Amjad Usman ${ }^{1 *}$, Arshad Khan ${ }^{1}$, Ruidar Ali Shah ${ }^{2}$ and Toheed Iqbal ${ }^{3}$
}

${ }^{1}$ Department of Entomology, The University of Agriculture, Peshawar, Khyber Pakbtunkbwa, Pakistan; ${ }^{2}$ Agricultural Research Institute Tarnab, Peshawar, Khyber Pakbtunkbwa, Pakistan; ${ }^{3}$ Department of Entomology, Amir Muhammad Khan Campus, Mardan, Khyber Pakbtunkbwa, Pakistan.

Abstract | Scirtothrips dorsalis is a devastating pest of tomato. The objective of this study was to screen commercially available tomato genotype and to identify the morphological plant characters responsible for resistance against $S$. dorsalis. For this purpose, five commercially cultivated tomato genotypes (Riogrande, Riogrande H, Bombino, Roma VF and Roma) were evaluated against thrips (S. dorsalis) at A.R.I. Tarnab, Peshawar, Pakistan during spring 2017 in randomized complete block design with three replications. Trichome study was also carried out to know the type of trichomes responsible for resistance. Results revealed that genotypes differed significantly in response to $S$. dorsalis populations. $S$. dorsalis infestation started on April $3^{\text {rd }}$ and peak population $(11.73 \pm 0.55)$ was noted on May $1^{\text {st }}$ on Bambino then population declined in the proceeding weeks, no $S$. dorsalis were recorded after June $22^{\text {nd }}$. In general, Roma supported lowest no. $(4.16 \pm 0.23)$ of $S$. dorsalis plant ${ }^{-1}$ and Riogrande supported the highest $(4.89 \pm 0.25)$ S. dorsalis plant $^{-1}$ and were found comparatively resistant and susceptible respectively. There were more glandular trichomes than non-glandular trichomes on leaves. Among the glandular trichomes, Type IV was the most abundant followed by Type VI whereas Type I and VII were rarely found on the leaf of the tested genotypes. Among the non-glandular trichomes, Type $\mathrm{V}$ was most abundant compared to II, III VIII. RomaVF had higher trichome density $\left(52.58 \pm 0.49\right.$ and $62.48 \pm 2.7$ per $\left.\mathrm{mm}^{2}\right)$ followed Bambino $(48.60 \pm 1.95$ and $49.71 \pm 71$ per $\left.\mathrm{mm}^{2}\right)$ and Roma $\left(45.82 \pm 2.11\right.$ and $51.65 \pm 2.47$ per $\left.\mathrm{mm}^{2}\right)$ on adaxial and abaxial leaf surfaces respectively. Negative relationship between $S$. dorsalis density with trichome density and type was observed in the tested tomato genotype. Morphological plant characters like glandular trichomes taking part in resistance against $S$. dorsalis can be used as an important tool in an integrated pest management model.

Received | March 21, 2019; Accepted | March 08, 2020; Published | April 17, 2020

*Correspondence | Amjad Usman, Department of Entomology, The University of Agriculture, Peshawar, Khyber Pakhtunkhwa, Pakistan; Email: amjadusman@aup.edu.pk

Citation | Usman, A., A. Khan, R.A. Shah and T. Iqbal.2020. Appraisal of Different Tomato Genotypes against Scirtothrips dorsalis (Thysanoptera: Thripidae) Infestation with Reference to Morphological Plant Characters. Sarbad Journal of Agriculture, 36(2): 375-382.

DOI | http://dx.doi.org/10.17582/journal.sja/2020/36.2.375.382

Keywords | Tomato genotypes, S. dorsalis Infestation, Trichome density, Trichome types

\section{Introduction}

$\mathrm{T}$ omato (Lycopersicum esculentum) is an important cash crop ranked second after potato globally (Adalid et al., 2004). In Pakistan, tomato is cultivated on a total area of 52.3 thousand hectares with a total production of 530,000 tons. In 2016-2017, among the five provinces across the country, Khyber Pakhthunkhwa ranks third with a production of 9.8 tones (Anonymous, 2018). 
In our country tomato yield is not satisfactory due to various biotic and abiotic factors. Among these, insect and diseases are the major constraints. Tomato crop is attacked by a number of insect pests including several species of thrips. Scirtothrips dorsalis (Thysanoptera: Thripidae) is minute polyphagous insect pest (Atakan, 2011) and both nymphs and adults feed upon the cellular content of leaves, resulting in white silvery spots (Koschier and Sedy, 2001). S. dorsalis infestation reduces photosynthesis which leads to shedding of flowers and fruits reducing fruit productivity. In case of severe infestation, the infested plant become curled wrinkled, dried and ultimately die (Kenedall and Capinera, 1987; Atwal, 1976).

Beside the direct damages, it is an important vector of many viral diseases e.g. tomato mosaic virus, tomato leaf curl virus, potato virus, cucumber mosaic virus, tomato yellow top virus, tomato spotted wilt virus and tomato ring spot virus in Pakistan causing 20-90\% losses in different crops (Mughal, 1995; Hameed, 1995; Hogenhout et al., 2008). Virus infection is difficult to control (Persley et al., 2007). Therefore, management strategy should focus on vector control.

In Pakistan, farmers mostly rely on synthetic insecticides for the control of $S$. dorsalis. However, the use of these insecticides results in development of insect resistance to insecticide, residue problems on crops and also has adverse effect on human health and the environment. To overcome such problems associated with the use of synthetic insecticides for $S$. dorsalis control. Host plant resistance plays a vital role as it is safe and compatible with all other control measures in an IPM program. Reduction in pest infestation to acceptable level has been reported due to the use of resistant variety alone or in combination with other control measures (Leuschner et al., 1985). Plant resistance to pests is influenced by morphological and biochemical plant factors specially the trichomes.

Trichomes are hairy structures originated from epidermal cells of plant and classified as glandular and non glandular (Glas et al., 2012). Glandular trichomes in tomato plant have been associated with the production of secondary metabolites or they may involve in the secretion of gummy or sticky exudates that hamper the insect (David and Eswaramoorty, 1988). While non glandular trichomes act as physical barrier that limiting insect contact with the host plant.
Trichomes density and its distribution on leaf surface are the best predictors of many herbivores resistance including homopterous insects Heinz and Zalom (1995). Resistance in several tomato genotypes to S. dorsalis has been reported by (Kumar et al., 1995; Mirnezhad et al., 2010; Vosman et al., 2018) due to the presence of type IV glandular trichomes that release acylsugars which form a sticky net that may trap insects (Mirnezhad et al., 2010; Leckie et al., 2016).

In Pakistan, work on morphological antixenosis mechanism of resistance in tomato to $S$. dorsalis infestation is very limit. Hence, the present study is an attempt to explore the antixenosis resistance level of commonly grown tomato cultivar of Khyber Pakhthunkhwa to $S$. dorsalis infestation.

\section{Materials and Methods}

Healthy tomato seedlings of uniform size of each genotype (Riogrande, Riogrande H, Bombino, Roma VFand Roma)were transplanted on $25^{\text {th }}$ of March 2017 at Agricultural Research Institute Tarnab (34.0123N, $\left.71.7074^{\circ} \mathrm{E}\right)$, Peshawar, Pakistan, in a Randomized Complete Block Design with three replications. Ten plants of each genotype were transplanted separately in experimental plot measuring $3 \mathrm{~m} \times 1.5 \mathrm{~m}$. Plant to plant and row to row distance were $45 \mathrm{~cm}$ and 90 $\mathrm{cm}$ respectively. Total experimental area was $12.5 \mathrm{~m}$ $\mathrm{x} 10 \mathrm{~m}$. All plots were exposed to natural infestation and no preventive measures were applied throughout the growing season. The data were recorded on the following parameters.

\section{S. dorsalis population density plant ${ }^{-1}$}

$S$. dorsalis population (nymph and adult) was recorded on five randomly selected plants at each observation. Number of nymph and adult were counted by giving a strong shake to the plant. All fallen $S$. dorsalis nymph and adult onto a white paper placed beneath the plant were counted with naked eye. Data was recorded on weekly basis for eight weeks from April $3^{\text {rd }}$ to June $22^{\text {nd }}$ ).

\section{Total yield $\left(\mathrm{kg} \mathrm{ha}^{-1}\right)$}

Tomatoes after each picking from each plot were weighted separately and the total yield of tomato was obtained by adding the yield from all pickings for each plot and then was converted to yield $\mathrm{kg}$ $\mathrm{ha}^{-1}$. 
Trichome density and leaf area $\left(\mathrm{cm}^{2}\right)$

Ten leaf samples of each genotype were selected for trichome study. Trichomes were counted on $1 \mathrm{~mm}^{2}$ transverse leaf portion on both the adaxial and abaxial leaf surface under trinocular stereo zoom microscope $350 \mathrm{X}$ with $5 \mathrm{Mp}$ Camera (NIKON, $\mathrm{SMZ} 745 \mathrm{~T})$. The same 10 leaves were selected for measuring leaf area with the help of leaf area meter (LICOR, LI-3100).

\section{Statistical analysis}

The data recorded on all the above parameters were subjected to analysis of variance and means were separated by using LSD test at 5\% level of significance by using Statistix 8.5. Correlation analysis was also carried out between the $S$. dorsalis density with trichomes density to find out morphological factors responsible for resistance in the tested tomato genotypes.

\section{Results and Discussion}

\section{Scirtothrips dorsalis population plant ${ }^{-1}$}

$S$. dorsalis plant ${ }^{-1}$ on different genotypes at weekly interval (April $3^{\text {rd }}$ to May 22 $2^{\text {nd }}$ ) were significant, varied from 0.06 to 11.73 plant $^{-1}$. S. dorsalis infestation started on April $3^{\text {rd }}$, However, Riogrande had lowest $S$. dorsalis population $\left(0.33 \pm 0.14\right.$ plant $\left.^{-1}\right)$ than other genotypes $\left(0.57 \pm 0.14-0.73 \pm 0.14\right.$ plant $\left.^{-1}\right)(F=10.67$; $d f=4 ; P=0.002) . S$. doralis population significantly increased in the subsequent weeks and reached to the peak on $1^{\text {st }}$ May where $S$. dorsalis population was significantly high on Bambino (11.73 \pm 0.55 plant $\left.^{-1}\right)$ and lowest on Roma VF $\left(8.86 \pm 0.20\right.$ plant $\left.^{-1}\right)$ $(F=17.98, d f=4 ; P=0.0005)$. Afterward, population decline in the successive weeks and diminished on May $22^{\text {nd }}$ with highest $S$. dorsalis density on Riogrande $\left(0.66 \pm 0.13\right.$ plant $\left.^{-1}\right)$ and lowest on Bambino and Roma $\left(0.13 \pm 0.14\right.$ plant $\left.^{-1}\right)$ respectively $(F=26.38, d f=4 ; P=$ 0.0001) (Figure 1).

Significant variation in average $S$. dorsalis population was recorded on different genotypes $(\mathrm{F}=8.67 ; \mathrm{df}=4$; $P<0.05)$. However, average seasonal population of $S$. dorsalis was significantly high $\left(4.89 \pm 0.25\right.$ plant $\left.^{-1}\right)$ on Riogrande and low on Roma (4.16 \pm 0.23 plant $\left.^{-1}\right)$. Response of the remaining genotype Riogrande H (4.40 \pm 0.21 plant $\left.^{-1}\right)$ and Bambino (4.51 \pm 0.14 plant $\left.^{-1}\right)$ and Roma VF $\left(4.33 \pm 0.33\right.$ plant $\left.^{-1}\right)$ were non significantly different from each other but significantly lower that Riogrande (Figure 2).
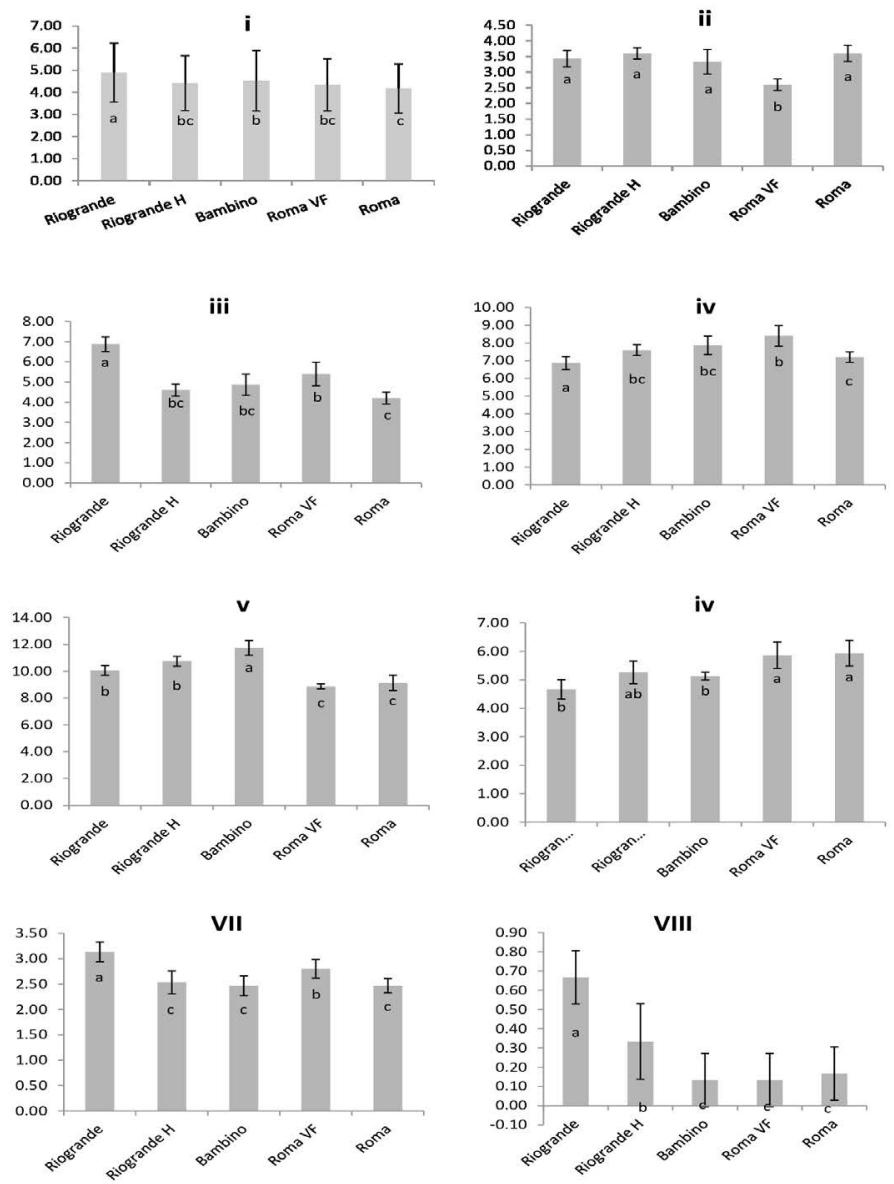

Figure 1: S. dorsalis population plant ${ }^{-1}$ on tomato genotypes on different dates i: $3^{\text {rd }}$ April; ii, $10^{\text {th }}$ April; iii, $17^{\text {th }}$ April; $24^{\text {th }}$ April; v, $1^{\text {st }}$ May; vi, $8^{\text {th }}$ May; vii, $15^{\text {th }}$ May; viii, $22^{\text {nd }}$ May 2017. Bars marked with different letters are significantly different at $(P<0.05)$.

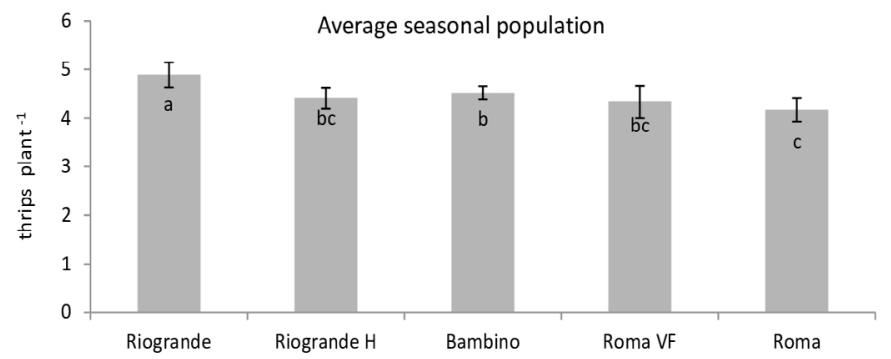

Figure 2: Average seasonal S. dorsalis population on tomato genotypes during 2017 ( $3^{\text {rd }}$ April to $22^{\text {nd }}$ May). Bars marked with different letters are significantly different at $(P<0.05)$.

\section{Trichomes density and leaf area}

Significant difference in leaf area was observed in the tested genotypes. Bigger leaf area of $31.47 \pm 0.74$ $\mathrm{cm}^{2}(\mathrm{~F}=14.04, \mathrm{df}=9, \mathrm{P}=0.001)$ was recorded in Riogrande $\mathrm{H}$, followed by Riogrande, Bambino, Roma VF and Roma ranging from 28.04 to 23.64 $\mathrm{cm}^{2}$ (Figure 3).

Trichome density on the adaxial and abaxial leaf surfaces was maximum in RomaVF followed by Bambino and Roma (Tables 1 and 2). In all genotypes, both the leaf surfaces possessed more glandular 
trichomes than non glandular. Glandular trichome on adaxial leaf surface was maximum in Roma VF $(34.58 \pm 0.80)$ followed by Roma $(31.75 \pm 1.41)$ and Bambino (30.94 \pm 0.94$)$ while on abaxial leaf surface glandular trichome was highest in Roma (39.24 \pm 2.02$)$ and Roma VF (38.64 \pm 2.01$)$. Similarly, non glandular trichomes were highest on adaxial leaf surface of Roma VF $(18 \pm 0.75)$ followed by Bambino $(17.66 \pm 1.01)$ and on abaxial leaf surface it was maximum in Roma VF (23.84 \pm 0.85$)$. Among the glandular trichome, Type IV was the most abundant on both the leaf surfaces followed by type VI while type I and VII glandular trichomes were very rare one on the leaves of selected genotypes. While Type $\mathrm{V}$ was the most abundant among the non glandular followed by type II while type III and VIII were the most rare one.

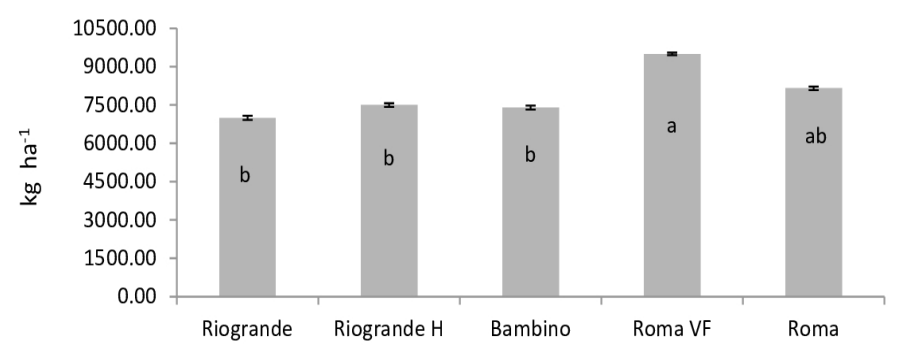

Figure 3: Yield of tomato different genotypes during 2017. Bars marked with different letters are significantly different at $(P<0.05)$.

Correlation analysis revealed $S$. dorsalis density is significantly affected by the trichome density and type (Table 3). Total trichome density on both the upper and lower leaf surfaces is negatively correlated with $S$. dorsalis density $(\mathrm{r}=-0.4710)$ and $(\mathrm{r}=-0.4392)$ respectively. Negative correlation also existed among both the glandular and no glandular trichomes on both the leaf surfaces. All types of non glandular trichomes were negatively correlated with $S$. dorsalis density. However, among glandular trichomes all types were negativelycorrelated with $S$. dorsalis density except type VI which showed positive correlation with $S$. dorsalis density on both the adaxial and abaxial leaf surfaces.

\section{Yield $\left(\mathrm{Kg}_{\mathrm{ha}} \mathrm{a}^{-1}\right)$}

The highest yield was recorded for Roma VF $\left(9504 \pm 147.22 \mathrm{~kg} \mathrm{ha}^{-1}\right)$ followed by Roma with yield of $8156 \pm 211.31 \mathrm{~kg} \mathrm{ha} \mathrm{h}^{-1}$. The genotype Riogrande $\mathrm{H}$, Bombino and Riogrande yielded $7499 \pm 213.62$, $7404 \pm 233.25$ and $7000 \pm 244.22 \mathrm{~kg} \mathrm{ha}^{-1}$ respectively. These being non-significant from each other but significantly lower than Roma VF than Roma VF (Figure 4).

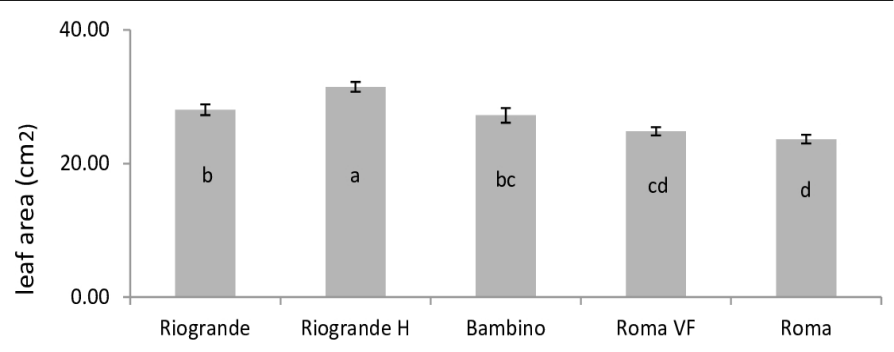

Figure 4: Leaf area of different tomato genotypes during 2017. Bars marked with different letters are significantly different at $(P<0.05)$.

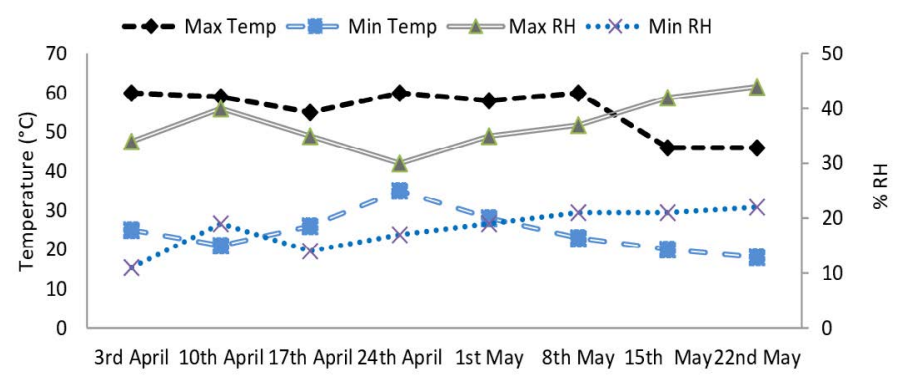

Figure 5: Temperature and Relative humidity recorded during tomato cropping season in Peshawar during 2017.

The genus Lycopersicum offers an array of defense traits against insect (Kennedy, 2003). S. dorsalis infestation varied significantly among Riogrande, Giogrande $\mathrm{H}$, Bambino, Roma VF and Roma. Riogrande was found the most preferred host plant that had highest $S$. dorsalis infestation. Roma was found the least preferred plant and had lowest $S$. dorsalis infestation (Figure 2). Variation in the $S$. dorsalis infestation could be due to difference in physical as well as biochemical factors of the tested genotypes.

S. dorsalis incident was highest at flowering stage compared to vegetative or mature stages which was also observed by Ssemwogerere et al. (2013) who indicated that the primary characteristic in thrips locate a host plant using visual clues such as the colors blue, white, and yellow (Terry, 1997). Childers and Brecht (1996) and De Kogel and Koschier (2003) found 60 times more thrips density on plants with flowers than plants of the same age without flowers.

Present study found peak $S$. dorsalis density in Peshawar area in $1^{\text {st }}$ week of May when plants were in flowering stage, when the max and min temperature was 17 and $30^{\circ} \mathrm{C}$ respectively with $35-55 \% \mathrm{RH}$ with very low precipitation (Figure 5). Thrips population is strongly influenced by climatic conditions (Lewis, 1997). The drier weather encourages the onset of thrips damage and severe the symptoms can be observed (Dobson et al., 2002). We also observed high $S$. dorsalis populations during optimum temperature with low 
Table 1: Mean number of Trichomes $\left(\mathrm{mm}^{-1} \pm S E\right)$ on adaxial leaf surface of different tomato genotypes.

\begin{tabular}{|c|c|c|c|c|c|c|c|c|}
\hline \multirow[t]{2}{*}{ Genotypes/ } & \multicolumn{3}{|c|}{ Glandular } & \multicolumn{2}{|c|}{ Non glandular } & \multirow{2}{*}{$\begin{array}{l}\text { Total } \\
\text { glandular }\end{array}$} & \multirow{2}{*}{$\begin{array}{l}\text { Total Non } \\
\text { glandular }\end{array}$} & \multirow{2}{*}{$\begin{array}{l}\text { Total } \\
\text { Trichomes } \\
\text { density }\end{array}$} \\
\hline & Type IV & Type VI & $\begin{array}{l}\text { Others } \\
(\mathrm{I}+\mathrm{VII})\end{array}$ & Type V & $\begin{array}{l}\text { Others } \\
\text { (II +III+VIII) }\end{array}$ & & & \\
\hline Riogrande & 19.00 & $3.28 \pm 0.15 \mathrm{a}$ & $0.95 \pm 0.09 c$ & 7.24 & $0.70 \pm 0.09 \mathrm{~b}$ & $1.07 \mathrm{c}$ & 7.95 & $31.19 \pm 1.89 c$ \\
\hline Riogrande $\mathrm{H}$ & $15.25 \pm 0.54 \mathrm{~d}$ & $2.07 \pm 0.12 b$ & & $6.83 \pm 0.65 c$ & $0.78 \pm 0.11 b$ & $18.21 \pm 0.46 \mathrm{~d}$ & $7.62 \pm 0.58 c$ & $25.83 \pm 0.38 \mathrm{~d}$ \\
\hline Bambino & $25.64 \pm 0.81 \mathrm{~b}$ & $3.28 \pm 0.14 \mathrm{a}$ & $2.02 \pm 0.13 b$ & $14.55 \pm 1.00 \mathrm{a}$ & $3.10 \pm 0.06 \mathrm{a}$ & $30.94 \pm 0.94 \mathrm{~b}$ & $17.66 \pm 1.01 \mathrm{a}$ & $48.60 \pm 1.95 b$ \\
\hline Roma VF & $29.83 \pm 0.87 \mathrm{a}$ & $3.12 \pm 0.14 \mathrm{a}$ & $1.62 \pm 0.06 \mathrm{~b}$ & $15.45 \pm 0.89 \mathrm{a}$ & $2.54 \pm 0.21 \mathrm{a}$ & $34.58 \pm 0.80 \mathrm{a}$ & $18.00 \pm 0.75 \mathrm{a}$ & $52.58 \pm 0.49 a$ \\
\hline Roma & $26.34 \pm 1.25 b$ & $1.45 \pm 0.09 c$ & $3.96 \pm 0.27 \mathrm{a}$ & $11.44 \pm 0.67 \mathrm{~b}$ & $2.63 \pm 0.28 \mathrm{a}$ & $31.75 \pm 1.41 \mathrm{ab}$ & $14.08 \pm 0.71 \mathrm{~b}$ & $45.82 \pm 2.11 \mathrm{~b}$ \\
\hline $\mathrm{LSD}_{(0}$ & 2.917 & 0.458 & 0.411 & 1.725 & 0.608 & 3.013 & 1.683 & 3.692 \\
\hline
\end{tabular}

Mean followed by different letters in each column is significantly different at 0.05 level of significance followed by LSD test.

Table 2: Mean number of Trichomes $\left(\mathrm{mm}^{-1} \pm S E\right)$ on abaxial leaf surface of different tomato genotypes.

$\begin{array}{lllllllll}\text { Genotypes } & \begin{array}{l}\text { Glandular } \\ \text { Type IV }\end{array} & \text { Type VI } & \begin{array}{l}\text { Others } \\ \text { (I+VII) }\end{array} & \begin{array}{l}\text { Non glandular } \\ \text { Type V }\end{array} & \begin{array}{l}\text { Others } \\ \text { (II +III+VIII) }\end{array} & \begin{array}{l}\text { Total } \\ \text { glandular } \\ \text { trichomes }\end{array} & \begin{array}{l}\text { Total non } \\ \text { glandular } \\ \text { trichomes }\end{array} & \begin{array}{l}\text { Total } \\ \text { trichomes } \\ \text { density }\end{array} \\ \text { Riogrande } & 23.73 \pm 0.58 \mathrm{c} & 4.11 \pm 0.60 \mathrm{a} & 1.74 \pm 0.15 \mathrm{c} & 10.48 \pm 0.63 \mathrm{~cd} & 0.65 \pm 0.04 \mathrm{c} & 29.60 \pm 0.72 \mathrm{~b} & 11.13 \pm 0.59 \mathrm{~cd} & 40.73 \pm 1.29 \mathrm{c} \\ \text { Riogrande } \mathrm{H} & 19.88 \pm 0.54 \mathrm{c} & 2.79 \pm 0.39 \mathrm{~b} & 1.24 \pm 0.13 \mathrm{c} & 9.27 \pm 0.11 \mathrm{~d} & 0.38 \pm 0.08 \mathrm{c} & 23.91 \pm 0.58 \mathrm{c} & 9.65 \pm 0.15 \mathrm{~d} & 33.57 \pm 0.71 \mathrm{~d} \\ \text { Bambino } & 25.57 \pm 0.88 \mathrm{~b} & 2.52 \pm 0.19 \mathrm{~b} & 2.46 \pm 0.48 \mathrm{bc} & 15.56 \pm 0.40 \mathrm{~b} & 3.59 \pm 0.13 \mathrm{~b} & 30.56 \pm 1.08 \mathrm{~b} & 19.15 \pm 0.52 \mathrm{~b} & 49.71 \pm 1.59 \mathrm{~b} \\ \text { Roma VF } & 31.59 \pm 1.64 \mathrm{a} & 3.72 \pm 0.12 \mathrm{ab} & 3.33 \pm 0.42 \mathrm{ab} & 18.88 \pm 0.68 \mathrm{a} & 4.94 \pm 0.19 \mathrm{a} & 38.64 \pm 2.01 \mathrm{a} & 23.84 \pm 0.85 \mathrm{a} & 62.48 \pm 2.71 \mathrm{a} \\ \text { Roma } & 30.53 \pm 1.65 \mathrm{a} & 4.24 \pm 0.51 \mathrm{a} & 4.46 \pm 0.60 \mathrm{a} & 11.87 \pm 0.52 \mathrm{c} & 0.54 \pm 0.11 \mathrm{c} & 39.24 \pm 2.02 \mathrm{a} & 12.41 \pm 0.45 \mathrm{c} & 51.65 \pm 2.47 \mathrm{~b} \\ \text { LSD }_{(0.05)} & 4.181 & 1.282 & 1.306 & 1.669 & 0.420 & 4.860 & 1.830 & 6.452\end{array}$

Mean followed by different letters in each column is significantly different at 0.05 level of significance followed by LSD test.

Table 3: Correlation analysis between Trichomes and thrips density of different tomato genotypes.

\begin{tabular}{|c|c|c|c|c|c|c|c|c|}
\hline \multirow[b]{2}{*}{$\begin{array}{l}\text { Trichomes type } \\
\text { /leaf surface }\end{array}$} & \multicolumn{3}{|c|}{ Glandular } & \multicolumn{2}{|c|}{ Non Glandular } & \multirow{2}{*}{$\begin{array}{l}\text { Total glan- } \\
\text { dular }\end{array}$} & \multirow{2}{*}{$\begin{array}{l}\text { Total non } \\
\text { glandular }\end{array}$} & \multirow{2}{*}{$\begin{array}{l}\text { Total trichomes } \\
\text { density }\end{array}$} \\
\hline & Type IV & Type VI & $\begin{array}{l}\text { Others } \\
(\mathrm{I}+\mathrm{VII})\end{array}$ & Type V & $\begin{array}{l}\text { Others } \\
\text { (II+III+VIII) }\end{array}$ & & & \\
\hline adaxal leaf surafce & -0.4735 & 0.6896 & -0.6742 & -0.4126 & -0.5593 & -0.4523 & -0.4768 & -0.4710 \\
\hline abaxial leaf surface & -0.5213 & 0.3418 & -0.6797 & -0.2782 & -0.1604 & -0.5240 & -0.2389 & -0.4392 \\
\hline
\end{tabular}

and infrequent rains which probably favored $S$. dorsalis build-up on tomato. Nizamani et al. (2002) reported that the population of thrips reached to peak in last week of June and $1^{\text {st }}$ week of July (avg temp $32^{\circ} \mathrm{C}$ ) then thrips population drastically decline up to $1^{\text {st }}$ week of August (avg temp $28^{\circ} \mathrm{C}$ ). While Sewify et al. (1996) observed peak population during July, August and September. Whereas, Gupta et al. (1997) revealed that $4^{\text {th }}$ week of July to $2^{\text {nd }}$ week of August is the most favorable period for peak thrips infestation. In our country no work has been done on thrips in tomato. So the present findings cannot be sticky compared with findings of the earlier researchers. As $S$. dorsalis is polyphagous pest and distributed worldwide so the variation in density and peak infestation period could be due its polyphagous nature and temperature variations in different ecological conditions.
Resistance in tomato to different herbivores has been associated to the presence to both non glandular and glandular leaf trichomes. In addition to being a physical barrier, glandular trichomes release different chemicals which are associated with pest resistance (Gil and Alvarez, 2015). Trichome study showed that all the selected tomato genotypes exhibited both the glandular and non glandular trichomes. Significant variation in trichome density and types were observed in tomato genotypes. Trichomes on tomato foliage have been categorized as Type I, IV, VI and VII are glandular while Type II, III, V which are non glandular (Luckwill, 1943). Irrespective of the genotype, it has been observed that abaxial leaf surface had more trichomes than adaxial leaf surface. Type IV trichomes were the most abundant on both the adaxial and abaxial leaf surface found in this study as well as reported by 
(Fernandez et al., 2003). Whereas Selvanarayanan and Naratanasamy (2006) reported that Type V trichome (non glandular) was the most abundant on tomato foliage. Such contradiction in trichome type could be possibility due to differences in genotypes and their genetic makeup of genotype. Type IV trichomes and Type I (which are rare on tomato leaves) are the source of acylsugur which combat insect attack by poising and stick insect (Weinhold and Baldwin, 2011). Furthermore, secretion of type VI trichome are the source of methyl ketones which are natural insecticides (Williams, et al., 1980) but methyl ketones has been reported in very low level in some tomato genotypes (Fridman, et al., 2005; Ben-Israel et al., 2009). Correlation analysis showed that trichome plays an important role in conferring resistance against $S$. dorsalis. Both glandular and non-glandular trichomes were observed to be negatively correlated with $S$. dorsalis density except type VI which was positively correlated with $S$. dorsalis density (Table 3). As type VI trichomes is the source of meth ketones is not predominantly found on tomato leaves of the tested genotypes used in this study might be one of the reason for positive correlation. Mirnezhad et al. (2010) clearly indicated resistance and susceptibility of tomato plant against thrips, is not influenced morphological plant character like by plant height toughness, leaves number and leaf area. Instead, resistance mainly influenced by chemistry of the glandular trichomes.

Significant difference among the tested genotypes was observed in term of yield. Such variation in yield may be due to genetic makeup of genotype. Present studies showed that genotypes with lower $S$. dorsalis infestation gave better yield. Such variation in yield among tomato genotypes due to insect pest has also been reported by (Rehman et al., 2000; Rida et al., 2002; Ahmad et al., 2007). Genotype Roma VF had less $S$. dorsalis density per plant gave maximum yield, while Bambino yielded minimum fruits had high $S$. dorsalis population. So under certain conditions, $S$. dorsalis may (along with other factors) contribute to yield. The absence of a strong correlation $(\mathrm{r}=0.224)$ between $S$. dorsalis population and yield suggests that the $S$. dorsalis populations encountered in this study were not a major factor in causing variation in yield of tomato fruit. So further study is needed in absence of other major insect pest of tomato to clarify the extent of losses by $S$. dorsalis in tomato crop.

\section{Conclusions and Recommendations}

This study provides base line information of $S$. dorsalis density on tomato crop in Peshawar area. None of the tested genotype was free from $S$. dorsalis infestation. However, the genotype Roma was found to be the comparatively resistant and Riogrande was found to be susceptible to $S$. dorsalis infestation among the tested genotypes. Density of glandular trichomes was dominant over non glandular and $S$. dorsalis infestation was influenced by the trichome density and type. Investigating biochemical analysis of glandular trichomes of the tested tomato genotypes could be a step towards development of a $S$. dorsalis resistant variety that can be incorporated into an IPM strategy.

\section{Novelty Statement}

This is the first study which indicates the occurrence of Scirtothrips dorsalis (Thysanoptera: Thripidae) on tomato in Peshawar, Khyber Pakhthunkhwa and its relationship with morphological plant characters of tomato plant.

\section{Author's Contribution}

$\mathrm{AU}$ and RAS presented the basic idea and designed research. AK principle investigator. AU analyzed the data and wrote the manuscript. TI made critical correction in the first draft.

\section{References}

Adalid, A.M., S. Rosello and F. Nuez. 2004. Breeding tomatoes for their high nutritional value. Rec. Res. Dev. P1. Sci. 2: 33-52.

Ahmad, F., Khan, O., Sarwar, S., Hussain, A. and Ahmad, S., 2007. Performance and evaluation of tomato cultivars at high altitude. Sarhad J. Agric., 23: 581-585.

Akemo, C.M., S. Kyamanywa, C. Ssekyewa, G.E. Luther, H. Wilson, M. Erbaugh and H. Warren. 1999. Developing IPM systems for tomato diseases and pests in central Uganda. In: "Integrated Pest Management Collaborative Research Support Program (IPM CRSP)". Sixth Annu. Rep. pp. 117-121.

Anonymous. 2018. Agricultural statistics of $\mathrm{Pa}-$ kistan, Government of Pakistan, Ministry of Food, Agriculture. pp. 24.

Atakan, E., 2011. Population densities and distri-

April 2020 | Volume 36 | Issue 2 | Page 380 
butions of the western flower thrips (Thysanoptera: Thripidae) and its predatory bug, Orius niger (Hemiptera: Anthocoridae), in strawberry. Int. J. Agric. Biol. 13: 638-644.

Atwal, A.S., 1976. Agriculture pest of india and South East Asia. Killiani Publ. Delhi. pp. 252253.

Ben-Israel, I., G. Yu, M.B. Austin, N. Bhuiyan, M. Auldridge, T. Nguyen, I. Schauvinhold, J.P. Noel, E. Pichersky and E. Fridman. 2009. Multiple biochemical and morphological factors underlie the production of methylketones in tomato trichomes, Plant Physiol. 151: 19521964. https://doi.org/10.1104/pp.109.146415

Childers, C.C. and J.K. Brecht. 1996. Colored sticky traps for monitoring Frankliniella bispinosa (Morgan) (Thysanoptera: Thripidae) during flowering cycles in citrus. J. Econ. Entomol. 89(5): 1240-1249. https://doi.org/10.1093/ jee/89.5.1240

David, H. and S. Eswaramoorty. 1988. Physical resistance mechanisms in insect-plant interactions. In: Dynamics of insect-plant interaction-recent advances and future trends. (eds. T.N. Ananthakrishnan and A. Raman), New Delhi: Oxford and IBH, pp. 45-70.

De Kogel, W.J. and E.H. Koschier. 2003. Thrips responses to plant odors. In: $7^{\text {th }}$ International symposium on thysanoptera: thrips, plants, tospoviruses: The millenial review (R. Marullo, L. Mound, eds.). Reggio Calabria, Italy, 2-7 July 2003. pp. 189-190.

Dobson H., J. Copper, W. Manyangarirwa, J. Karuma and W. Chiimba. 2002. Integrated vegetable pest management: safe and sustainable protection of small-scale brassicas and tomatoes. A handbook for extension staff and trainers in Zimbabwe. NRI, Univ. Greenwich, UK. pp. 179

Fernandez, R., M. Munoz, M. Salinas, J. Alvarez and J. Cuartero. 2003. Inheritance of resistance to two-spotted spider mite and glandular leaf trichomes in wild tomato Lycopersicon pimpinellifolium (Jusl.) J. Am. Soc. Hort. Sci. 128: 188-195. https://doi.org/10.21273/ JASHS.128.2.0188

Fridman, E., J. Wang, Y. Iijima, J.E. Froehlich, D.R. Gang,J. Ohlrogge and E. Pichersky. 2005. Metabolic, genomic, and biochemical analyses of glandular trichomes from the wild tomato species Lycopersicon hirsutum identify a key enzyme in the biosynthesis of methylketones, Plant
Cell. 17: 252-1267. https://doi.org/10.1105/ tpc.104.029736

Gil, M. and Alvarez. 2015. Review on insect resistance in tomato (Solanum Spp.). Cultivos Tropicales. 36(2): 100-110.

Glas, J.J., B.C. Schimmel, J.M. Alba, R. Escobar-Bravo, R.C. Schuurink and M.R. Kant. 2012. Plant glandular trichomes as targets for breeding or engineering of resistance to herbivores. Int. J. Mol. Sci. 13: 17077-17103. https:// doi.org/10.3390/ijms131217077

Gupta, M.P., S. Sandeep, S.K. Shrivastava and S. Sharma, 1997. Population build up of some sap sucking insects on cotton in Madhya Pardesh.J. Insect Sci., 10: 153-156

Hameed, S., 1995. Leaf curl virus resistance in tomato and chilies. Final Report, South Asian Vegetable Research Network. Virol. Sect. (CDRI), NARC, Islamabad. pp. 75.

Heinz, K.M. and F.G. Zalom. 1995. Variation in trichome based resistance to Bemisia argentifolii (Homoptera: Aleyrodidae) oviposition on tomato. J. Econ. Entomol. 88(5): 1494-1502. https://doi.org/10.1093/jee/88.5.1494

Hogenhout, S.A., E-D. Ammar, A.E. Whitfield and M.G. Redinbaugh. 2008. Insect vector interactions with persistently transmitted viruses. Ann.Rev.Phytopathol.46:327-359.https://doi. org/10.1146/annurev.phyto.022508.092135

Kenedall, D.M. and J.L. Capinera. 1987. Susceptibility of onion growth stages to onion thrips (Thysanoptera: Thiripidae) damage and mechanical defoliation. Environ. Entomol.16(4): 859-863. https://doi.org/10.1093/ee/16.4.859

Kennedy, G.G., 2003. Tomato, pests, parasitoids, and predators: Tritrophic interactions involving the genus Lycopersicon. Ann. Rev. Entomol. 48: 51-72. https://doi.org/10.1146/annurev. ento.48.091801.112733

Koschier, E.H. and K.A. Sedy. 2001. Effects of plant volatiles on the feeding and oviposition of Thrips tabaci. Thrips Tospoviruses. pp. 185-187.

Kumar, K.N.K., D.E. Ullman and J.J. Cho. 1995. Resistance among Lycopersicon species to Frankliniella occidentalis (Thysanoptera: Thripidae). J. Econ. Entomol. 88: 1057-1065. https:// doi.org/10.1093/jee/88.4.1057

Leckie, B.M., D. Ambrosio, D.A., Chappell, T.M., Halitschke, R., D. Jong, D.M. and A. Kessler. 2016. Differential and synergistic functionality of acylsugars in suppressing oviposition by 
insect herbivores. PLoS One. 11: e0153345. https://doi.org/10.1371/journal.pone.0153345

Leuschner, K., S.L. Taneja and H.C. Sharma. 1985. The role of host-plant resistance in pest management in sorghum in India. Int. J. Trop. Insect Sci. 6(03): 453-460.

Lewis, T., 1997. Flight and dispersal. In: Thrips as crop pests (T. Lewis, ed.). CAB International, Wallingford, UK. 736 pp. 175-196.

Kuckwill, L.C. 1943. The genus Lycopersicon. A Historical, Biological and Taxonomic Survey of the wild and cultivated tomatoes. Aberdeen University Studies number 120. Aberdeen Univ. Press.UK. pp. 43.

Mirnezhad, M., R.R. González, K.A. Leiss, Y.H. Choi, R. Verpoorte and P. Klinkhamer. 2010. Metabolomic analysis of host plant resistance to thrips in wild and cultivated tomatoes. Phyto. Chem. Anal., 21(1): 110-117. https://doi. org/10.1002/pca.1182

Mughal, S.M., 1985. Viral diseases of tomato and their control Prog. Fing. 6(2): 20-23.

Nizamani, I.M., M.A. Talpur, R.D. Khuhro and S.M. Nizamani. 2002. Relative resistance of cotton cultivars to sucking complex. Pak. J. Appl. Sci., 2: 686-689. https://doi.org/10.3923/ jas.2002.686.689

Persley, D., M. Sharman, J. Thomas, I. Kay, S. Heisswolf and L. McMichael. 2007. Thrips and tospovirus: a management guide. Cooperative Research Centre for Tropical Plant Pathology, DPIF, Queensland. pp. 10.

Rehman, F., S. Khan, Faridullah and Shafiullah, 2000. Performance of different tomato cultivars under climatic conduction of northern areas (Gilgit). Pak. J. Biol. Sci. 3: 833-835. https:// doi.org/10.3923/pjbs.2000.833.835

Rida, A.S., A.A. Muhammad, I.E. Ereifij and A. Hussian. 2002. Evaluation of thirteen open pollinated Cultivars and three hybrids of tomato
(Lycopersicum esculentum) for yield physiological disorder, seed production and vegetative growth. Pak. J. agric. Res., 17: 290-296.

Selvanarayanan, V. and P. Narayanasamy. 2006. Factors of resistance in tomato accessions against the fruit worm, Helicoverpa armigera (Huebner). Crop Protec. 25(10): 1075-1079.

Sewify, G.H., S.A. E1-Arnaouty and M.H. Belal. 1996. The effect of cotton late planting on population densities of sucking insects and their associated predators in Giza region, Egypt. Bull. Fac. Agric. Univ. Cario. 47: 665 - 675.

Ssemwogerere, C., M.K.N.O. Ssemakula, J. Kovach, S. Kyamanywa and J. Karungi. 2013. Species composition and occurrence of thrips on tomato and pepper as influenced by farmers' management practices in Uganda. J. P1. Protec. Res. 53 (2):160-164. https://doi.org/10.2478/jppr2013-0024

Terry, I., 1997. Host selection, communication and reproductive behavior. p. 65-118. In: "Thrips as Crop Pests" (T. Lewis, ed.). CAB Int., Oxon, pp. 736.

Vosman, B., W.C.V. Westende, B. Henken, H.D.L.M. Eeckelen, R.C.H. Vos and R.E. Voorrips. 2018. Broad spectrum insect resistance and metabolites in close relatives of the cultivated tomato. Euphytica. 214: 46. https:// doi.org/10.1007/s10681-018-2124-4

Weinhold, A. and I.T. Baldwin. 2011. Trichome-derived $\mathrm{O}$-acyl sugars are a first meal for caterpillars that tags them for predation, Proc. Natl. Acad. Sci. USA. 108: 7855-7859. https://doi. org/10.1073/pnas.1101306108

Williams, W.G., G.G. Kennedy, R.T. Yamamoto, J.D. Thacker and J. Bordner.1980. 2-Tridecanone: a naturally occurring insecticide from the wild tomato Lycopersicon birsutum $\mathrm{f}$. glabratum. Sci. pp. 207. https://doi.org/10.1126/science.207.4433.888 